\title{
Response of Different level of Nitrogen and Phosphorus on Soil health, Growth and Yield attributes of Radish (Raphanus sativas L.)
}

\author{
Choppari Shiva Kumar*, Narendra Swaroop, Arun Alfred David, Tarence Thomas, \\ Dudekula Sarmas Vali and Odapally Vinay Kumar
}

Department of Soil Science and Agricultural Chemistry, Sam Higginbottom University of
Agriculture, Technology and Sciences, Prayagraj -211 007, (U.P), India

*Corresponding author

\section{A B S T R A C T}

\section{Keywords}

Nitrogen,

Phosphorus,

Growth, Yield,

Quality and radish

Article Info

Accepted:

20 October 2020

Available Online:

10 November 2020
The present investigation entitled Response of different level of Nitrogen and Phosphorus on Soil health, Growth and Yield attributes of Radish (Raphanus sativus L.) was carried out in Rabi season during 2019-20 in Sam Higginbottom University of Agriculture, Technology and Sciences, Prayagraj district of Uttar Pradesh India. The experiment consisted of 9 treatment combinations and which were replicated thrice and laid out in a randomized block design. The results showed that progressive increase in the soil $\mathrm{pH}, \mathrm{EC}$ and water holding capacity, available nitrogen and phosphorus respectively gave the best results in $\mathrm{T}_{9^{-}}$ [Nitrogen@100\% + Phosphorus @ 100\%] in Radish (Raphanus sativus L.) were to be found the best treatment combinations.

\section{Introduction}

Radish (Raphanus sativus L.) is a member of the Brassicaceae family native to Europe or Asia. It is a popular root crop grown all over the world. In India, it is grown in one or the other part of the country throughout the year. It is grown for its young fleshy tuberous roots consumed mainly as salted vegetable, eaten as a grated salad. Radish is a cool season crop and divided broadly into two groups: European or temperate and Asiatic or tropical. Asiatic types produce roots and seeds under tropical climate, whereas, European types produce roots under sub tropical and tropical climate. However, seed production of European types is possible only under temperate conditions in hills since these require chilling temperature for seed production. The Asiatic varieties although are higher yielders yet poor in quality attributes, whereas, European varieties are small in size, mild in pungency, early in maturity and rich in quality parameters (Tripathi et al., 2017). Radish the most important root crop is grown widely all over the country. It is annual and biennial crop which botanical name is Raphanus sativus, originated in Europe and 
Asia. It is mainly cool season crop which is popular in both tropical and temperate regions. The fleshy edible portion of the root develops from both primary root as well as the hypocotyl. Roots vary greatly in size, shape and other external characteristics as well as in the length of time they remain edible. Radish is a cool season vegetable but can tolerate high temperature. The best quality roots are produced at temperature between 10 to $15.5^{\circ} \mathrm{C}$. Roots may acquire a repulsive flavour and become more fibrous and mature early at higher temperature. Radish contains glucose as the major sugar and smaller quantities of fructose and sucrose. It is also good source of vitamin- $\mathrm{A}$ and $\mathrm{C}$ and also rich source of minerals like calcium, potassium and phosphorus.

Nitrogen plays an important role in the building up of protoplasm and protein which induce cell division and initiate meristematic activities when applied in optimum quantity. Low nitrogen availability causes a decrease in cell size especially cell division (Akand et al., 2015). Nitrogen improves the absorption \& respiration process in plant and activates vegetation. Radish plants with more leaves can give more root yield as compared to the plants having less leaves. Nitrogen is the main component of protein \& chlorophyll.

It plays vital role in transferring energy with in plant cells, cell division, and formation of meristem tissue; promote root growth, flowering and development of seed and fruit. Deficiency of phosphorus leads to reddish or purple leaves, stems and branches, stunted top growth that results in low yield and ultimately poor quality of crops (Zeb et al., 2016). And also the Deficiency of Phosphorus limits the production of plant because the mobility of Phosphorus is low in soil and the root system. To explore its mobility in plant and its role in plant top development, 10 and $20 \mathrm{mg} / \mathrm{l}$ phosphorus in radish was applied. Fresh and dry matter increased with phosphorus application (Kezia and David, 2013).

\section{Materials and Methods}

The soil of experimental area falls in order of Inceptisols and soil is a alluvial in nature. The samples randomly collected from five different sites in the experimental plot prior to tillage operations from a depth of $0-15 \mathrm{~cm}$. the size of the entire soil sample was reduced by conning and quartering process the remaining soil was dried under shade and passed through a $2 \mathrm{~mm}$ sieve by way of preparing the sample for physical and chemical analysis. The experimental details are given below. The experiment considered of 9 treatments which were replicated thrice and laid out in a randomised block design. The treatment combinations are $\mathrm{T}_{1}$ - absolute control, $2_{2}$ - Nitrogen @ 0\% + Phosphorus @ $50 \%, \mathrm{~T}_{3^{-}}$Nitrogen @0\% + Phosphorus @ 100\%, T4-Nitrogen @ 50\% + Phosphorus @ $0 \%, \quad \mathrm{~T}_{5} \quad-\quad$ Nitrogen@50\%+ Phosphorus@50\%, T6-Nitrogen @50\% + Phosphorus@100\%, T 7 -Nitrogen@100\%+ Phosphorus@0\%, T8-Nitrogen@100\%+ Phosphorus @50\%, T9-Nitrogen@100\%+ Phosphorus @100\%.The experiment was conducted on the research farm of department of soil science and agricultural chemistry, Sam Higginbottom University of Agriculture, Technology and Sciences, Prayagraj city on the bank of Yamuna river, the experimental site was located in the sub-tropical region with $25.43^{\circ} \mathrm{N}$ latitude, $81.84^{\circ} \mathrm{E}$ longitude and $98 \mathrm{~m}$ above from the MSL.

\section{Results and Discussion}

Data presented in Table 1 showed that there was a significant effect on specific gravity and a non-significant effect on soil $\mathrm{pH}$ and soil EC by different treatment combinations. The maximum Organic carbon content, water holding capacity $(0.77 \%, 66.67 \%)$ was 
recorded in the treatment combination $\mathrm{T}_{9}$ [Nitrogen@100\% + Phosphorus @ 100\%] available nitrogen and available phosphorus (395.94 $\mathrm{kg} \mathrm{ha}^{-1}$ and $46.48 \mathrm{ha}^{-1}$ ) was recorded in the treatment combination $\mathrm{T}_{9}$ [Nitrogen@100\% + Phosphorus @100\%] but the maximum available potassium in soil $\left(189.98 \mathrm{~kg} \mathrm{ha}^{-1}\right)$ was recorded in the treatment combination $\quad \mathrm{T}_{7}$-[Nitrogen@100\% + Phosphorus @0\%] followed by $\mathrm{T}_{8}-[100 \%$ nitrogen $+\% 50$ phosphorus] is noticed as second best treatment after $\mathrm{T}_{8}$ compared with treatment combination $\mathrm{T}_{1}$ [absolute control] (Table 1-4 and Fig. 1-4).

Table.1 Response of different level of nitrogen and phosphorus on Bulk density, Particle density and specific gravity of the soil

\begin{tabular}{|c|c|c|c|c|}
\hline $\begin{array}{l}\text { S. } \\
\text { No. }\end{array}$ & Treatment combination & $\begin{array}{c}\text { Bulk } \\
\text { density } \\
\left(\mathrm{g} \mathrm{cm}^{-3}\right)\end{array}$ & $\begin{array}{l}\text { Particle } \\
\text { density } \\
\left(\mathrm{g} \mathrm{cm}^{-3}\right)\end{array}$ & $\begin{array}{l}\text { specific } \\
\text { gravity }\end{array}$ \\
\hline 1. & $\mathrm{~T}_{1}$ - absolute control & 1.24 & 2.36 & 2.14 \\
\hline 2. & $\mathrm{~T}_{2^{-}}$Nitrogen@0\%+Phosphorus@50\% & 1.23 & 2.41 & 2.26 \\
\hline 3. & T3- Nitrogen@0\%+Phosphorus@100\% & 1.20 & 2.54 & 2.30 \\
\hline 4. & T4-Nitrogen@50\%+Phosphorus@0\% & 1.18 & 2.61 & 2.35 \\
\hline 5 . & 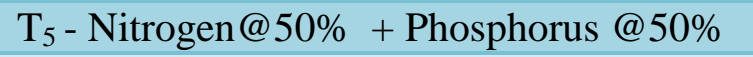 & 1.16 & 2.68 & 2.40 \\
\hline 6. & T6-Nitrogen@50\% + Phosphorus @100\% & 1.15 & 2.65 & 2.34 \\
\hline 7. & T7-Nitrogen@100\% +Phosphorus@0\% & 1.16 & 2.71 & 2.40 \\
\hline 8. & T/-Nitrogen@100\% +Phosphorus @ 50\% & 1.14 & 2.76 & 2.53 \\
\hline \multirow[t]{4}{*}{9.} & T9-Nitrogen@100\% + Phosphorus@100\% & 1.12 & 2.84 & 2.58 \\
\hline & F-Test & NS & NS & $\mathrm{S}$ \\
\hline & C.D at $0.5 \%$ & 5.15 & 0.05 & 0.1 \\
\hline & S.Ed( $( \pm)$ & 2.43 & 0.23 & 0.05 \\
\hline
\end{tabular}

Table.2 Response of different levels of nitrogen and phosphorus on solid space, Water holding capacity and pore space of the soil

\begin{tabular}{|c|c|c|c|c|}
\hline S. No. & Treatment combinations & $\begin{array}{c}\text { Solid space } \\
(\%)\end{array}$ & $\begin{array}{c}\text { W.H.C } \\
(\%)\end{array}$ & $\begin{array}{c}\text { Pore } \\
\text { space }\end{array}$ \\
\hline 1. & $\mathrm{~T}_{1}$ - absolute control & 36.75 & 61.27 & 51.13 \\
\hline 2. & $\mathrm{~T}_{2}$ - Nitrogen@0\%+Phosphorus@50\% & 37.39 & 62.39 & 51.44 \\
\hline 3. & 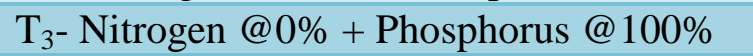 & 37.55 & 63.44 & 54.15 \\
\hline 4. & T4-Nitrogen@50\%+Phosphorus@0\% & 38.15 & 63.87 & 59.01 \\
\hline 5. & $\mathrm{~T}_{5}$ - Nitrogen@50\% + Phosphorus @50\% & 38.37 & 64.70 & 62.34 \\
\hline 6. & 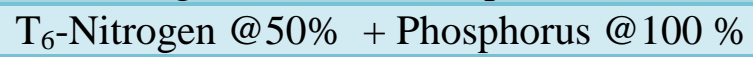 & 38.51 & 65.78 & 62.07 \\
\hline 7. & T7-Nitrogen@100\% +Phosphorus@0\% & 39.56 & 65.23 & 63.29 \\
\hline 8. & T8-Nitrogen@100\% +Phosphorus@ @50\% & 42.65 & 65.95 & 63.96 \\
\hline \multirow[t]{4}{*}{9.} & T9-Nitrogen@100\% + Phosphorus@100\% & 44.49 & 66.11 & 64.41 \\
\hline & F-Test & NS & $\mathrm{S}$ & $\mathrm{S}$ \\
\hline & C.D at $0.5 \%$ & 0.65 & 0.76 & 1.77 \\
\hline & $\operatorname{S.Ed}( \pm)$ & 0.30 & 0.36 & 0.55 \\
\hline
\end{tabular}


Table.3 Response of different levels of nitrogen and phosphorus on soil $\mathrm{pH}$, electrical conductivity and organic carbon of soil in radish

\begin{tabular}{|c|l|c|c|c|}
\hline S. No. & Treatment combinations & soil pH & $\begin{array}{c}\text { Electrical } \\
\text { Conductivity } \\
\left(\mathbf{d S m}^{-\mathbf{1}} \mathbf{)}\right.\end{array}$ & $\begin{array}{c}\text { Organic } \\
\text { carbon } \\
\mathbf{( \% )}\end{array}$ \\
\hline $\mathbf{1 .}$ & $\mathrm{T}_{1}$ - absolute control & 7.60 & 0.03 & 0.56 \\
\hline $\mathbf{2 .}$ & $\mathrm{T}_{2}$ - Nitrogen @ 0\% + Phosphorus @ 50\% & 7.62 & 0.03 & 0.61 \\
\hline $\mathbf{3 .}$ & $\mathrm{T}_{3}$ - Nitrogen @ 0\% + Phosphorus @ 100\% & 7.73 & 0.04 & 0.63 \\
\hline $\mathbf{4 .}$ & $\mathrm{T}_{4}$-Nitrogen @ 50\% + Phosphorus @ 0 \% & 7.64 & 0.04 & 0.64 \\
\hline $\mathbf{5 .}$ & $\mathrm{T}_{5}$ - Nitrogen @ 50\% + Phosphorus @ 50\% & 7.68 & 0.03 & 0.66 \\
\hline $\mathbf{6 .}$ & $\mathrm{T}_{6}$-Nitrogen @ 50\% + Phosphorus @ 100\% & 7.71 & 0.03 & 0.65 \\
\hline $\mathbf{7 .}$ & $\mathrm{T}_{7}$-Nitrogen @ 100\% + Phosphorus @ 0\% & 7.73 & 0.04 & 0.71 \\
\hline $\mathbf{8 .}$ & $\mathrm{T}_{8}$-Nitrogen @ 100\% + Phosphorus @ 50\% & 7.72 & 0.04 & 0.73 \\
\hline $\mathbf{9 .}$ & $\mathrm{T}_{9}$-Nitrogen@ 100\% + Phosphorus @ 100\% & 7.75 & 0.04 & 0.73 \\
\hline & F-Test & $\mathrm{NS}$ & $\mathrm{NS}$ & $\mathrm{NS}$ \\
\hline & C.D at 0.5\% & 0.06 & 0.01 & 0.06 \\
\hline & S.Ed(+) & 0.02 & 0.04 & 0.03 \\
\hline
\end{tabular}

Table.4 Response of different levels of nitrogen and phosphorus on available nitrogen, phosphorus and potassium of the soil

\begin{tabular}{|c|c|c|c|c|}
\hline $\begin{array}{l}\text { S. } \\
\text { No. }\end{array}$ & Treatment combinations & $\begin{array}{l}\text { Nitrogen } \\
\left(\mathrm{kg} \mathrm{ha}^{-1}\right)\end{array}$ & $\begin{array}{l}\text { Phosphorus } \\
\left(\mathrm{kg} \mathrm{ha}^{-1}\right)\end{array}$ & $\begin{array}{c}\text { Potassium } \\
\left(\mathrm{kg} \mathrm{ha}^{-1}\right)\end{array}$ \\
\hline 1. & $\mathrm{~T}_{1}$ - absolute control & 224.81 & 24.13 & 139.42 \\
\hline 2. & $\mathrm{~T}_{2^{-}}$Nitrogen @ 0\% + Phosphorus @ 50\% & 262.50 & 27.33 & 149.87 \\
\hline 3. & $\mathrm{~T}_{3}$ - Nitrogen @0\% + phosphorus @ 100\% & 272.09 & 29.48 & 149.87 \\
\hline 4. & T4-Nitrogen @ 50\% + Phosphorus @ 0\% & 287.58 & 35.50 & 176.90 \\
\hline 5. & $\mathrm{~T}_{5}$ - Nitrogen@50\% + Phosphorus @ 50\% & 330.83 & 35.55 & 149.87 \\
\hline 6. & $\mathrm{~T}_{6}$-Nitrogen @ 50\% + Phosphorus @ $100 \%$ & 337.75 & 37.32 & 149.87 \\
\hline 7. & T7-Nitrogen@100\% + Phosphorus @ 0\% & 341.75 & 41.26 & 187.25 \\
\hline 8. & T8-Nitrogen@100\% + Phosphorus @ 50\% & 350.61 & 44.49 & 176.94 \\
\hline \multirow[t]{4}{*}{9.} & T9-Nitrogen@100\% + Phosphorus@ @100\% & 375.94 & 45.72 & 176.90 \\
\hline & F-Test & $\mathrm{S}$ & $\mathrm{S}$ & $\mathrm{S}$ \\
\hline & C.D at $0.5 \%$ & 14.3 & 2.00 & 4.27 \\
\hline & S.Ed $( \pm)$ & 6.2 & 0.94 & 2.01 \\
\hline
\end{tabular}


Fig.1 Interaction effect of integrated nutrient management on bulk density, particle density and specific gravity of soil

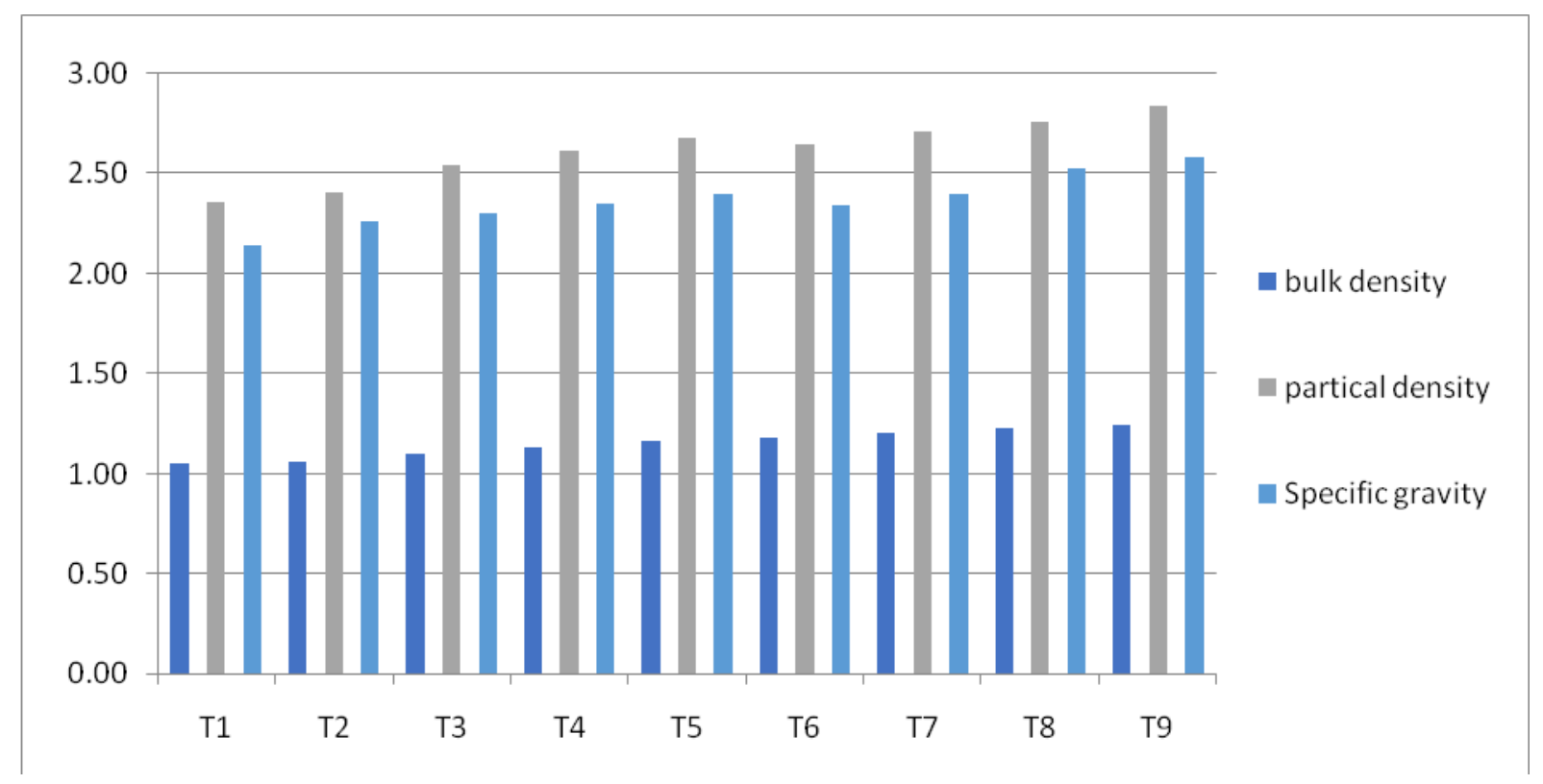

Fig.2 Interaction effect of different levels of nitrogen and phosphorus on solid space (\%) water holding capacity and pore space of soil

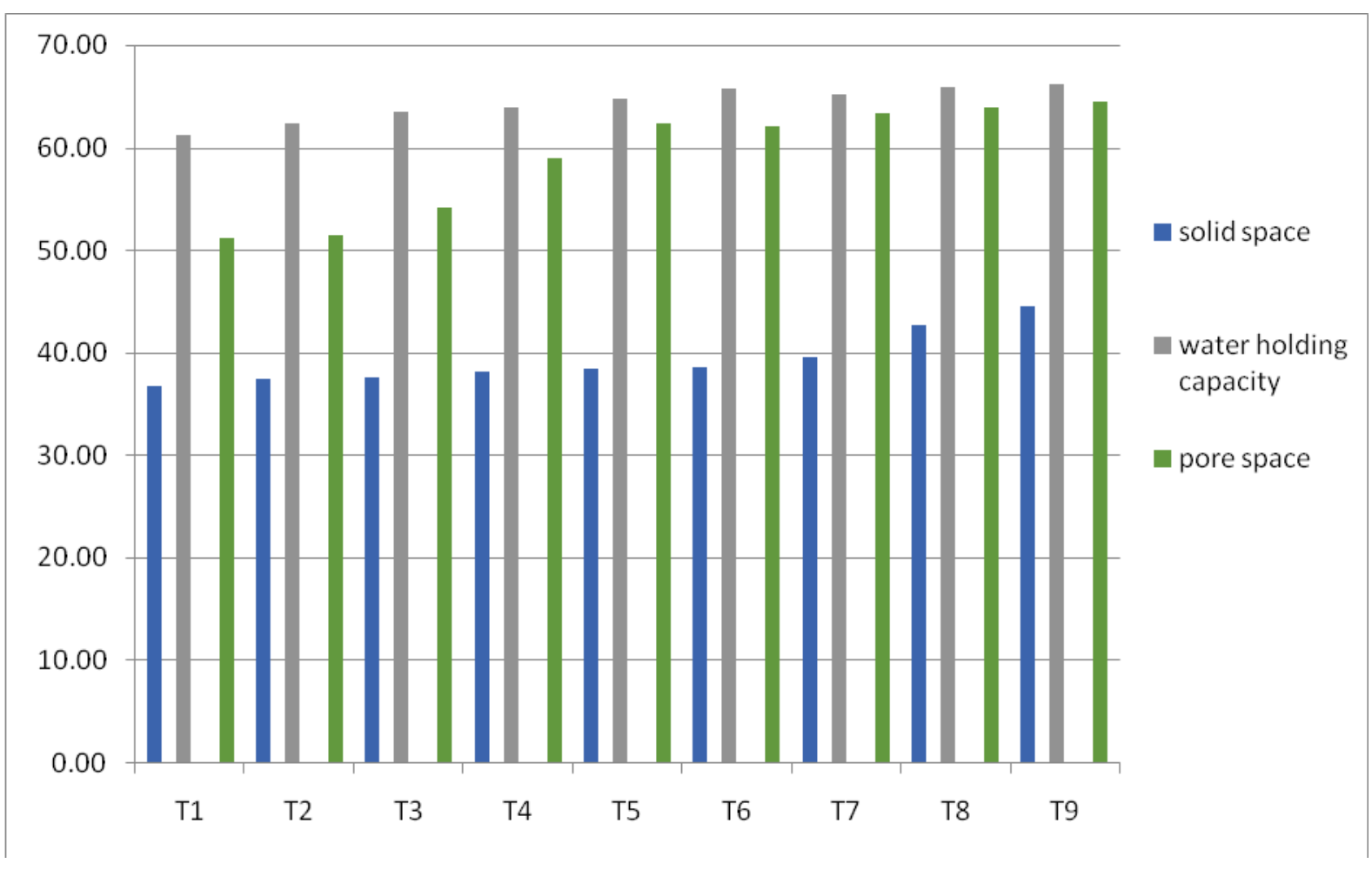


Fig.3 Interaction effect of different levels of nitrogen and phosphorus on soil $\mathrm{pH}$, electrical conductivity and organic carbon of soil

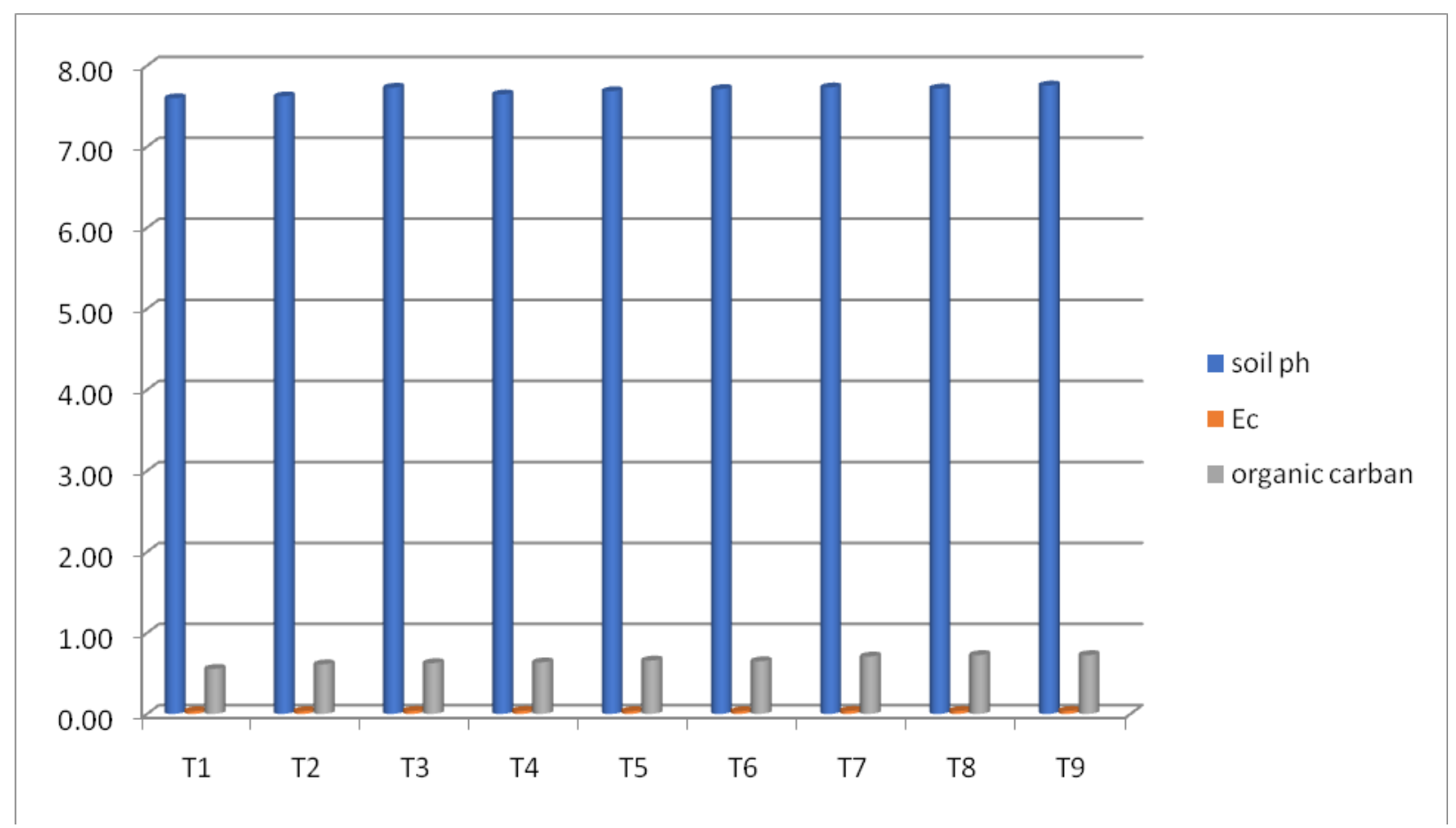

Fig.4 Interaction effect of different levels of nitrogen and phosphorus on available nitrogen, phosphorus and potassium in soil

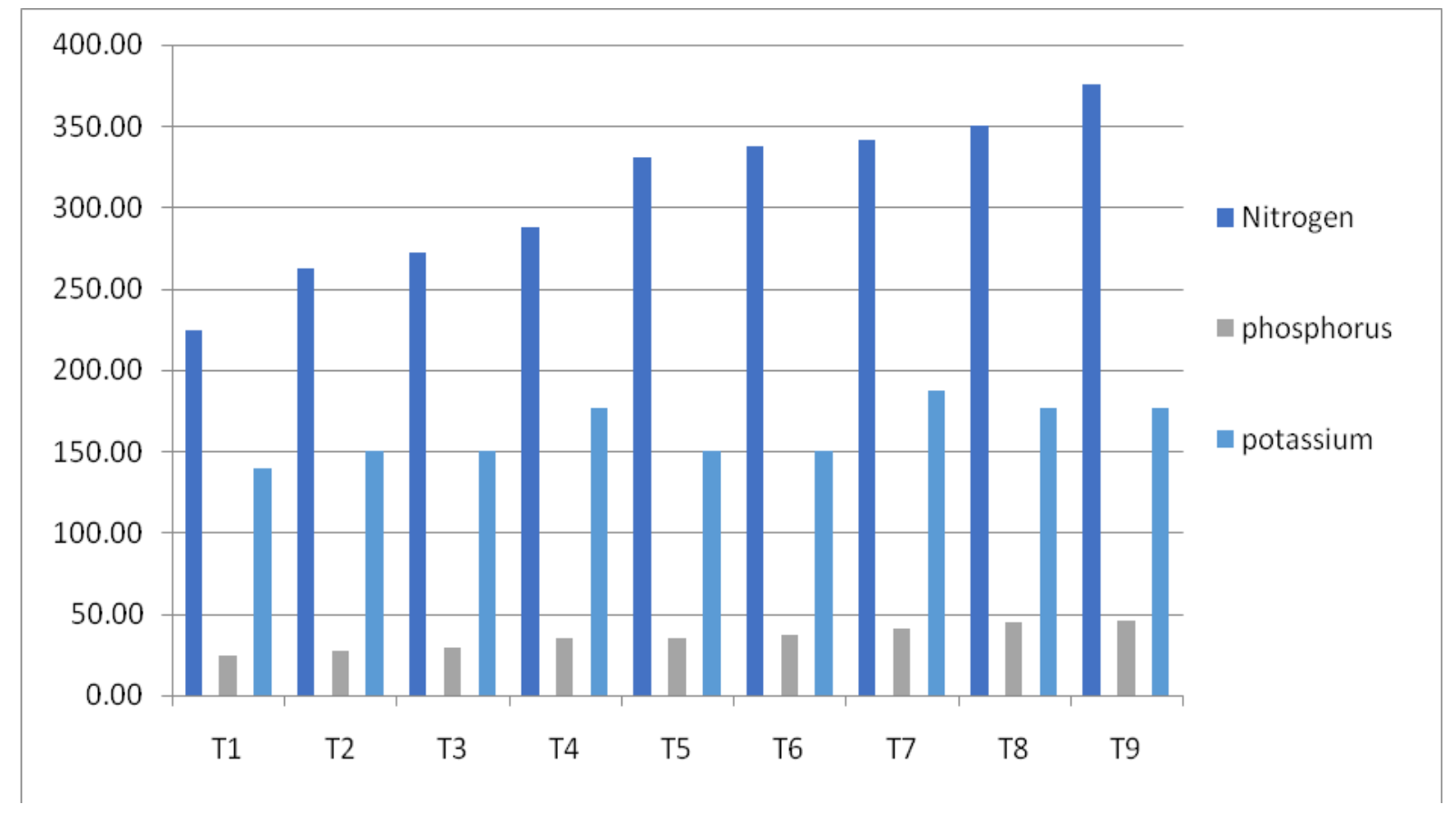


The maximum Bulk density was observed in the treatment combination $\mathrm{T}_{1}$-[absolute control] there was non-significant variation between various treatment combinations there was a non-significant effect on bulk density and solid space.

Similar findings had been reported by Kamalakannan and Manivannan (2003) stated that levels of nitrogen and phosphorus is the best approach to supply adequate and balanced nutrients and increase crop productivity in an efficient and environmentally benign manner, without sacrificing soil productivity of future generations. It is also found that by Jilani et al., (2010). The maximum $\mathrm{N}$ and $\mathrm{P}$ uptake was noted when $100 \%$ RDF at the rate of one $\mathrm{tha}^{-1}$.

The experiment was conducted at the Research Farm of Soil Science and Agricultural Chemistry, Sam Higginbottom University of Agriculture, Technology and Sciences, Prayagraj during Rabi season 2019 2020 study the "Response of different levels of nitrogen and phosphorus on soil health, Growth and yield attributes of Radish (Raphanus sativas L.)" in prayagraj soil.

The treatments were allocated in a randomized block design with three replications. The treatments consisted of combination of different levels of nitrogen and phosphorus.

The crop was sown $20^{\text {th }}$ December 2019 with a seed rate of $10 \mathrm{~kg} \mathrm{ha}^{-1}$ and harvested on $19^{\text {th }}$ January 2020.The observation taken on different plant characters during the crop growth period and at crop harvest.

The general results of the investigation are summarized below:

The plot treated with treatment combination T $9^{-}$[Nitrogen@100\% + Phosphorus@ @ 100\%] there was significant increase in vegetative growth and yield attributes. At this level there was slight increase in $\mathrm{pH}$ and decrease in EC but increase in nutrient status of soil.

The plot treated with the treatment combination $\quad \mathrm{T}_{7}$-[Nitrogen@100\%+ Phosphorus @0\%] there was significant increase in available potassium in soil. This treatment is showing nearly similar results with treatment combination $\mathrm{T}_{8}$.

In conclusion, the treatment combination $\mathrm{T}_{9}$ [Nitrogen@100\% + Phosphorus @100\%] given the significant result in the terms of soil quality parameters like soil pore space, specific gravity, available NPK. The $\mathrm{pH}$, EC and solid space non-significant. From the economical point of view the same treatment combination gave the maximum profit of R.s 1,36,462.00 ha ${ }^{-1}$ with $\mathrm{B}: \mathrm{C}$ ratio of 1:5.52 and it was very closely followed by treatment combination $\quad \mathrm{T}_{8}$-[Nitrogen@100\% + Phosphorus @50\%] as they compared with treatment combination $\mathrm{T}_{1}$-[absolute control]. Nitrogen and phosphorus might have supplies continuous slow release and increased more available nutrients, which aided in better growth parameters.

\section{Acknowledgement}

The author is thankful to the honourable vice chancellor, HOD, advisor and non-teaching staff of Department of Soil Science and Agricultural chemistry, Sam Higginbottom University of Agriculture, Technology and Sciences, Prayagraj Uttar Pradesh for providing all necessary facilities and clarify studies.

\section{References}

Akand MDH, Mazed HEMK, Pulok MdAI, Moonmoon JF, Partho SG. Influence of different dose of nitrogen on the growth and yield of cabbage (Brassica oleracea 
var. capitata L.) Inter. J. Multidisciplinary Res. and Development. 2015; 2(2): 11-14.

Akoumianakis, K. A. and Karapanos, I. C. (2011) .Nitrogen, season and cultivar affect radish growth, yield, sponginess and hollowness. International Journal of Plant Prod., 5(2): 111-119.

Bilekudari, M. K. Deshpande, V. K. Shekhargouda, M. (2005). Effect of spacing and fertilizer levels on growth, seed yield and quality of radish. Karnataka Journal of Agricultural Sciences. 18:2, 338-342.

Bodkhe, V.A.Mahorkar, V.K. (2010). Effect of various organic manures on growth, yield and quality of radish. International J. Agri. Sci., 6: (1) 72-73.

Borisov, V. A. Tenkov, A. L. (2004). Yield and quality of radish, garden radish and daikon in Moscow province. [Russian] Kartofel ' i Ovoshchi. 2, 22-23.

Dod, V. N. Java Giri Manisha Deshmukh More, G. B. (2010). Effect of plant spacings on seed yield and quality of radish. Annals of plant physiology.24: 1, 110-111.

El-Desuki, M. Salman, S. R. El - Nemr, M. A.and Abdel - Mawgoud, A. M. R. (2005). Effect of plant density and nitrogen application on the growth, yield and quality of radish (Raphanus sativus L.). Journal of Agronomy. 4(3), 225-229.

Ermokhin, Yu, I. Bobrenko, E. G. and Bobrenko, I.A. (2004) Varietal characteristics of radish productivity and quality with the use of fertilizers. Russian Agricultural Sciences. 10(5): 8-
12.

Gonge; V. S. Bhole, M. S. and Deshmukh, D. T. (2003). Effect of plant density and nitrogen levels on root yield and quality of radish (Raphanus sativus L.) var. Pusa Chetki. Orissa J.Horti., 31(1): 8284.

Guvenc, I. (2002). Effect of nitrogen fertilization on growth, yield and nitrogen contents of radishes. Gartenbauwissenschaft; 67: (1) 23-27, 19.

Jilani, M. S. Tariq Burki Kashif Waseem (2010) Effect of nitrogen on growth and yield of radish. Journal of Agricultural Research (Lahore). 48(2): 219-225.

Kamalakannan and Manivannan (2003) Response of radish for grades levels of nitrogen and phosphorus along with biofertilizers. South Indian Horti., 51: (1/6), 199-203.

Kezia EJ, David SJ. The effect of organic and Inorganic fertilizers on the growth of radish. IOSR-JHSS. 2013; 17(3): 51-55.

Tripathi AK, Ram RB, Rout S, Kumar A, Patra SS, Effect of Nitrogen Levels and Spacing on Growth and Yield of Radish (Raphanus sativus L.) Cv. Kashi Sweta, Int. J. Pure App. Biosci. 2017; 5(4): 1951-1960.

Zewide I, Mohammed A, Tulu S. Effect of different rates of nitrogen and phosphorus on yield and yield components of potato (Solanum tuberosum L.) at Masha District, South western Ethiopia. International Journal of Soil Science. 2012; 7: 146-156.

\section{How to cite this article:}

Choppari Shiva Kumar, Narendra Swaroop, Arun Alfred David, Tarence Thomas, Dudekula Sarmas Vali and Odapally Vinay Kumar. 2020. Response of Different level of Nitrogen and Phosphorus on Soil health, Growth and Yield attributes of Radish (Raphanus sativas L.). Int.J.Curr.Microbiol.App.Sci. 9(11): 2534-2541. doi: https://doi.org/10.20546/ijcmas.2020.911.307 